\title{
INDUCED BREEDING OF FRESH WATER MENODA CATFISH (Hemibagrus menoda) USING OVUPIN HORMONE
}

\author{
Islam, N., M. F. Islam ${ }^{1}$, M. S. Islam ${ }^{1}$ and M. I. Miah \\ Department of Fisheries Management, Bangladesh Agricultural University, Mymensingh, Bangladesh; \\ ${ }^{1}$ Department of Fisheries, Bangamata Sheikh Fojilatunnesa Mujib Science and Technology University, \\ Melandah, Jamalpur, Bangladesh
}

\begin{abstract}
An experiment on induced breeding of menoda catfish, Hemibagrus menoda was conducted during the period from May 2017 to July 2018 by using commercial Ovupin hormone (GnRHa, Gonadotropin Releasing Hormone Analogues) to attain its optimum dose. The study consists of three treatments, each with three replications. The objective of the experiment was to find out the effective dose for induced breeding. The breeding parameters were determined in terms of ovulation, fertilization, hatching, and survival rate. A total of 36 males and 18 females lived brood fish were kept in the ratio of $2 \delta^{\lambda}: 1+$ for breeding purpose. The commercial Ovupin hormone were injected at the doses of $4\left(\mathrm{~T}_{1}\right), 6\left(\mathrm{~T}_{2}\right), 7\left(\mathrm{~T}_{3}\right) \mathrm{mL}$ Ovupin $\mathrm{kg}^{-1}$ body weight for female and 1.5( $\left.\mathrm{T}_{1}\right), 2\left(\mathrm{~T}_{2}\right), 3\left(\mathrm{~T}_{3}\right) \mathrm{mL}$ Ovupin $\cdot \mathrm{kg}^{-1}$ body weight for male in a triplicate replication. In this study, it was found that treatment $T_{2}$ demonstrated the best spawning performance for both male and female and were statistically significant $(\mathrm{p}<0.05)$. The investigation indicated that the dose of Ovupin hormone $6 \mathrm{~mL}$ Ovupin $\cdot \mathrm{kg}^{-1}$ body weight for female and $2 \mathrm{~mL}$ Ovupin $\mathrm{kg}^{-1}$ body weight for male determines the highest spawning performance of menoda catfish which should be recommended for high quality eggs and larvae.
\end{abstract}

Key words: Hemibagrus menoda; Induced breeding; Menoda catfish; Ovupin.

\section{INTRODUCTION}

Induced breeding of catfish is the most potential and dependable technique for ensuring the availability of good quality fish seeds all year round. Catfishes hardly reproduce in the captive water body so artificial propagation is the only way for an enormous source of superior seeds and culture in the different water bodies which will increase the total fish production as well as the GDP of a country. In the freshwaters of Bangladesh, almost 55 species of catfish belonging to 35 genera have been reported to date (Rahman 2005). In recent years, the production of these catfishes has increased, but the appearance of many species of catfishes is falling day by day from natural waters (Hoque et al. 1998).

The production of fish seeds all year round has been made possible due to induced breeding techniques (Ayinla and Akande 1988). Various types of commercial hormones such as Pitutary Gland (PG), Deoxycorticosterone Acetate (DOCA), Ovaprim, Ovulin, Human Chorionic Gonadotropin (HCG), Ovopel, Dagin and Aquaspawn etc. are used for artificial propagation of different catfishes and these hormones are most familiar in the markets (Cheah and Lee 1980, Brzuska and Adamek 1999, Zohar and Mylonas 2001, Adebayo and Popoola 2008). The effectiveness of using different doses of synthetic hormones have been recorded for artificial propagation of different catfishes (Olubiyi et al. 2005, Sahoo et al. 2005, Achionye-Nzeh and Obaroh 2012, Shinkafi and Ilesanmi 2014, Marimuthu et al. 2015); but very little is known about the doses of Ovupin in catfish breeding. Moreover, it is probably the first study of induced breeding of Hemibagrus menoda (Hamilton 1822) by using Ovupin hormone.

$H$. menoda, a catfish having the common name Menoda catfish, is locally known as Golsa-tengra, Arwari, Gang magur, Kounemagur in Bangladesh. The habitats of $H$. menoda range from the Ganges, Brahmaputra, Mahanadi and Godavari River drainages in Bangladesh to northern India. H. menoda has been utilized as experimental animal and is a valuable food fish because of its large size (450 mm or 17.7" SL, but can attain up to $800 \mathrm{~mm}$ ), tasty flesh and high market value. But it is less frequently encountered in markets compared to other genera of large Bagrid catfishes such as Rita and Sperata 
(Hoque et al. 1998, Ng and Ferraris 2000). H. menoda was categorized as Near Threatened (IUCNBangladesh 2015) because of its rapid disappearance from the rivers, haors and beels of Bangladesh. With a view to conserving this fish, this study attempts to develop conservation strategies through constructing an induced breeding protocol because $H$. menoda does not spawn naturally in captive conditions. In addition to conservation, successful induced breeding of $H$. menoda may lead to successful culture of this fish. Considering the value and significance of $H$. menoda, the present experiment was undertaken to estimate the effective dose of hormone for the induced breeding of the species.

\section{Brood fish collection and rearing}

\section{MATERIAL AND METHODS}

The research activities were carried out in the Field Laboratory Complex of Fisheries Faculty in Bangladesh Agricultural University, Mymensingh during May 2017 to July 2018. The brood fishes of Gang magur, Hemibagrus menoda fish (Fig. 2a) were collected from Jhanjail point-1, Kongsho River of the Netrokona district in May 2017 (Fig. 1). They were reared in earthen rectangular ponds of the Field Laboratory complex. During the rearing period, SIS (small indigenous species of fish) and protein and vitamin-E enriched feed was fed to the fish at a rate of 3.5-5\% body weight. Fertilization, manuring, and liming were performed regularly whenever necessary.

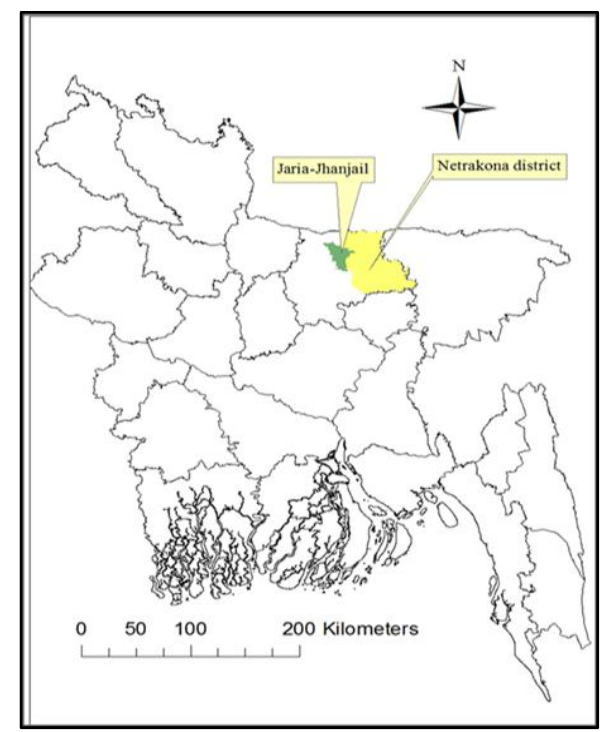

a

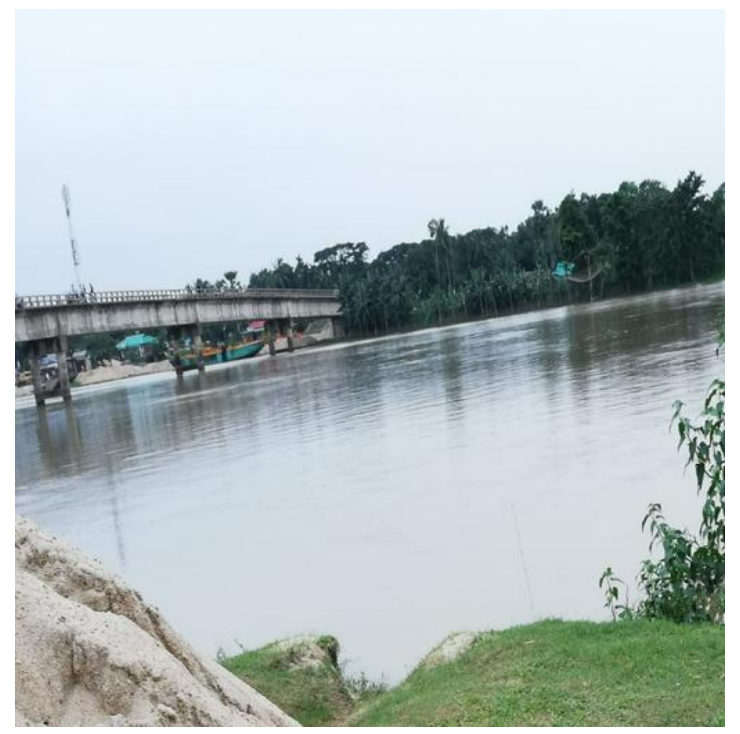

b

Fig. 1. Pictorial view: a. site map; and b. study area.

\section{Brood selection and conditioning}

The average weight of the males and females were $354 \pm 42 \mathrm{~g}$ and $738 \pm 67 \mathrm{~g}$ respectively. Males were relatively smaller, elongated and slender in shape than females. The gravid males and females were selected based on the following criteria: a) males have swollen and reddish urogenital papillae (Fig. 2b); b) females have rounded and protruding abdomen which is soft when touched with fingers and swollen genital opening sometimes reddish in color (Fig. 2c). The selected broods were shifted to the circular cemented tank with continuous water showering for about five hours prior to administering hormones. During conditioning, males and females were kept off-feed. 


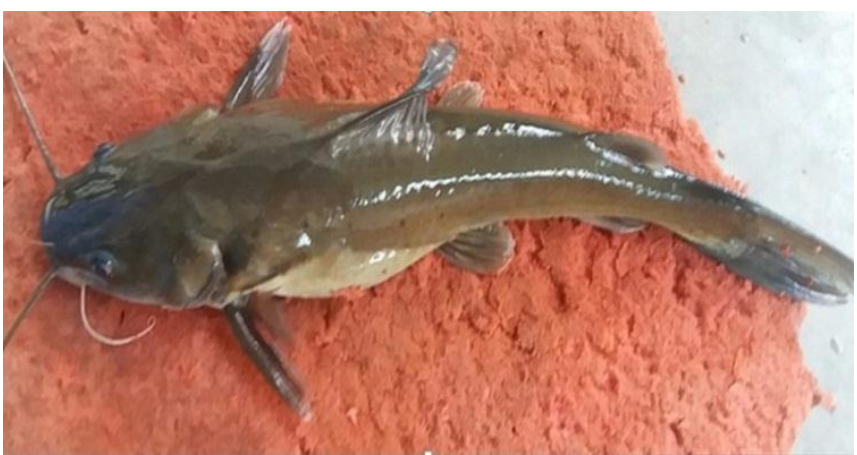

a

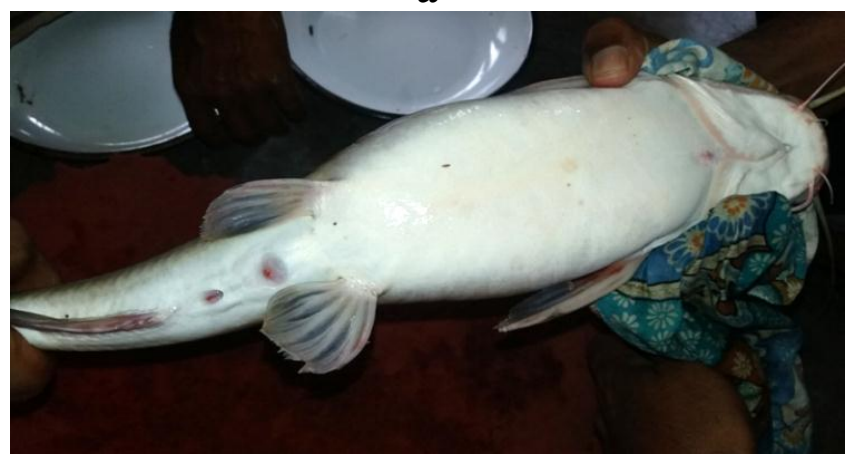

c

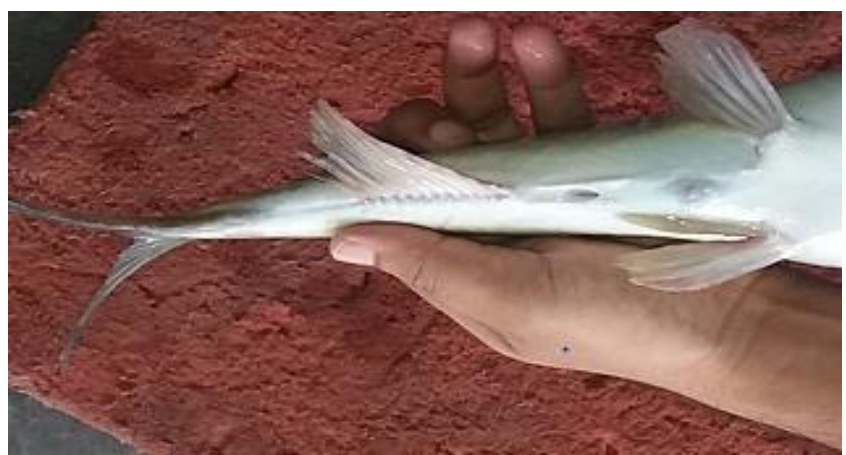

b

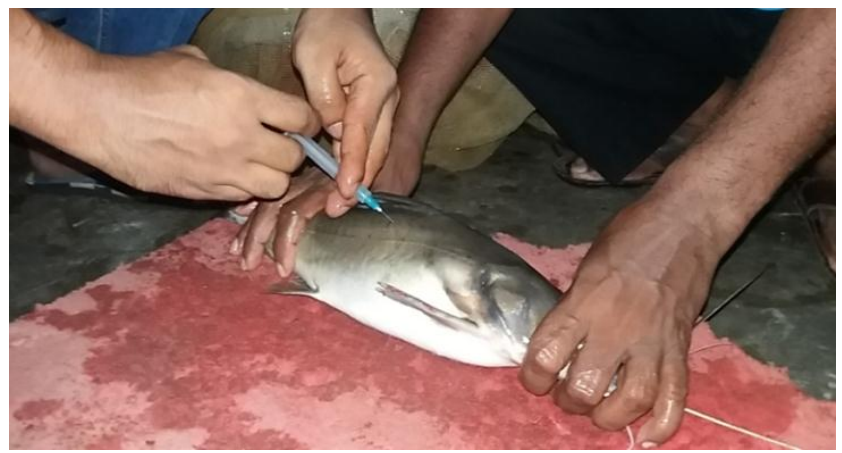

d

Fig. 2: Pictorial view of Gang magur, Hemibagrus menoda: a. Mature state; b. Ventral view of mature male; c. Ventral view of mature female showing swollen abdomen; and $\mathbf{d}$. Injection of ovupin hormone to the brood fish.

\section{Collection of Ovupin hormone and preparation of its solution}

For induced breeding purpose, Gonadotropin Releasing Hormone analogues ( $\mathrm{GnRHa}$ ) commercially known as Ovupin (100 mg Domperidone + $0.2 \mathrm{mg} \mathrm{S}-\mathrm{GnRHa}$ ) were used in this study. Ovupin hormone vial was bought from a reputed shop in Mymensingh town. The proper doses of Ovupin hormone were calculated based on the recommended dose and body weight of the brood fish using this formula:

Where,

$$
\text { Amount of ovupin }(m l)=\frac{W t \times P t}{1000}
$$

$\mathrm{Wt}=$ total body weight of the fish injected $(\mathrm{g})$;

$\mathrm{Pt}=$ the rate in $\mathrm{mL}$ Ovupin injected $\cdot \mathrm{kg}^{-1}$ body weight for a particular treatment.

For Ovupin preparation, the powder form of the synthetic hormone was diluted with distilled water to dissolve it in the contained vial and shook for a few minutes. Then, the prepared solution was taken in a $5 \mathrm{~mL}$ disposable syringe for injection.

\section{Experimental design}

This experiment was carried out using commercial Ovupin hormone consisting of three treatments$\mathrm{T}_{1}, \mathrm{~T}_{2}$, and $\mathrm{T}_{3}$, each with three replications. The total 54 lived brood fish which were taken and kept them at a ratio of 2 male: 1 female in the tanks. Semi artificial (or induced natural) propagation method was adopted which involved synchronized spawning in breeding hapa whereby the injected brood fish (male and female spawners) were placed into a breeding hapa fixed in circular and rectangular tanks (dimensions: $1.22 \times 2.74 \times 0.37 \mathrm{~m}$ ). Double hapa (upper and lower) were used. After ovulation and fertilization, the upper hapa was removed along with the spent spawners while the fertilized eggs settled in the lower hapa which served as a shelter during the incubation period. Some larvae also hatched in the hapa. 


\section{Hormone injection}

The weights of selected brood fish and amount of needed Ovupin hormone solution were measured. Then a disposable graduated syringe of $5 \mathrm{~mL}$ was used for injecting the hormone to brood fish. The hormone solution was administered intramuscularly to the female $\left(4,6,7 \mathrm{~mL}\right.$ Ovupin $\cdot \mathrm{kg}^{-1}$ body weight $)$ and male $\left(1.5,2,3 \mathrm{~mL}\right.$ Ovupin $\cdot \mathrm{kg}^{-1}$ body weight) between the dorsal fin and lateral line maintaining about $45^{\circ}$ angular position with the body (Fig. 2d). The injected fish were then kept into breeding hapas placed in tanks for synchronized spawning at the ratio of $20^{\wedge}: 19$ (temperature $26^{\circ} \mathrm{C} ; \mathrm{pH} 7.5$; dissolved oxygen $6.5 \mathrm{ppm}$ ) and their reproductive behaviour were closely monitored. It was observed that the males were in ceaseless pursuance of the females though most often they remained together very closely under the shower.

\section{Ovulation, determination of fertilization rate and incubation of eggs}

After $24 \mathrm{~h}$ of injection, all of fish were found ovulated. Ovulation and fertilization occurred in the spawning hapa. After ovulation the upper hapa was removed along with the spent spawners leaving the fertilized eggs. Approximately 100 eggs were placed in plastic bowls to determine fertilization rate with three replications of each and water flow was ensured using porous PVC pipe and outlet facility. Fertilized eggs were identified using a magnifying glass and then counted with the help of a soft thin brush. The ovulation and fertilization rate were determined by using the following formula (Mollah et al. 2008):

$$
\begin{aligned}
& \text { Ovulation rate }(\%)=\frac{\text { No.of fish ovulated }}{\text { Total no. of fish injected }} \times 100 \\
& \text { Fertilization rate }(\%)=\frac{\text { No.of fertilized eggs }}{\text { Total no. of eggs }} \times 100
\end{aligned}
$$

\section{Determination of hatching rate}

The larvae were separated from unhatched eggs by siphoning with a $1.5 \mathrm{~mm}$ rubber hose. Then the larvae were closely observed to see the time of yolk sac absorption for first feeding of larvae. Aerators were used through the systems for aeration. After completion of hatching, about $6 \mathrm{~h}$ post hatching; the number of larvae/hatchlings in each bowl was counted by siphoning them out. The hatching rate was determined by using the following formula (Islam et al. 2011):

$$
\text { Hatching rate }(\%)=\frac{\text { No. of eggs hatched }}{\text { Total no. of fertilized eggs }} \times 100
$$

\section{Determination of survival rate}

For determination of survival rate, 300 hatchlings were randomly collected from each replication under a particular treatment and stocked in the trays for 10 days (without feeding). During the experimentation, all other conditions were maintained same. The number of total live larvae in the tray was counted at $10^{\text {th }}$ day of the experiment for calculation of survival rate.

\section{Physico-chemical parameters analysis}

The temperature, dissolved oxygen (DO) and $\mathrm{pH}$ value of water were ranged between $26{ }^{\circ} \mathrm{C}$ to 29 ${ }^{\circ} \mathrm{C}, 5.5$ to $6.5 \mathrm{ppm}$ and 6.7 to 7.5 respectively under different treatments.

Statistical analyses: The data were subjected to a one-way analysis of variance (ANOVA) followed by Duncan's Multiple Range Test (DMRT) at a significance level of $p<0.05$. The computer software SPSS version 20 was used for statistical analysis. 


\section{RESULTS AND DISCUSSION}

Spawning responses of Hemibagrus menoda injected with Ovupin hormone

The doses of Ovupin given, latency period, incubation temperature and spawning responses of the fish are showed in Table 1.

Table 1. Spawning responses of Hemibagrus menoda to different doses of Ovupin at $19: 2 \AA$ ratio.

\begin{tabular}{cccccl}
\hline Treatment & $\begin{array}{c}\text { Ovupin dose (mL } \\
\text { Ovupin } \mathbf{k g}^{-1} \text { body weight) }\end{array}$ & $\begin{array}{c}\text { Latency } \\
\text { period (h) }\end{array}$ & $\begin{array}{c}\text { Incubation } \\
\text { temperature }\left({ }^{\circ} \mathbf{C}\right)\end{array}$ & Remarks \\
\cline { 2 - 5 } & + & 0 & 24.5 & $26-27$ & $\begin{array}{l}\text { Complete ovulation, considerable number of } \\
\text { larvae hatched but survival rate was poor. }\end{array}$ \\
\hline $\mathrm{T}_{1}$ & 4 & 1.5 & 24 & $26-27$ & $\begin{array}{l}\text { Successful ovulation, considerable number } \\
\text { of larvae hatched and survived. }\end{array}$ \\
\hline $\mathrm{T}_{2}$ & 6 & 2 & 25 & $27-29$ & $\begin{array}{l}\text { Amount of ovulation was very little, hence a } \\
\text { few numbers of larvae hatched and survived }\end{array}$ \\
\hline $\mathrm{T}_{3}$ & 7 & 3 & & & \\
\hline
\end{tabular}

\section{Ovulation rate}

From the experiment the highest average ovulation rate (100\%) was found both in $\mathrm{T}_{1}$ and $\mathrm{T}_{2}$ whereas the lowest value $\left(66.67 \%\right.$ ) was found in $\mathrm{T}_{3}$ (Table 2). The ANOVA test showed that $\mathrm{T}_{3}$ was significantly $(\mathrm{p}<0.05)$ lower than $\mathrm{T}_{1}$ and $\mathrm{T}_{2}$. However, no significant difference was found between $\mathrm{T}_{1}$ and $\mathrm{T}_{2}(\mathrm{Table}$ $2)$. The ovulation rate $(100.0 \pm 0.0 \%)$ indicates highly mature brood fish in better brood stock management practice with special diet. Rahdari et al. (2014) stated that lack of synchronization was attributed due to long time of latency in the achievement of readiness of spawning by the fish. Hasan et al. (2021) have observed that ovulation rate was $100 \%$ and $63 \%$ when Hemibagrus menoda was induced by Ovatide hormone at the rate of $5 \& 3 \mathrm{~mL}$ Ovatide $\cdot \mathrm{kg}^{-1}$ body weight for female and $2.5 \& 1.5 \mathrm{~mL}$ Ovatide $\mathrm{kg}^{-1}$ body weight for male which is more or less similar to the present findings. Mollah et al. (2008) reported that for riverine catfish (Rita rita), the dose of Pituitary Gland (PG) at the rate of 80, 100,120 and $140 \mathrm{mg} \cdot \mathrm{kg}^{-1}$ body weight resulted $0 \%, 100 \%, 100 \%$ and $100 \%$ ovulation, respectively.

Table 2. Breeding performance (mean $\pm \mathrm{SD}$ ) of Hemibagrus menoda with different doses of Ovupin hormone.

\begin{tabular}{ccccc}
\hline Treatment & Ovulation rate $(\%)$ & Fertilization rate $(\%)$ & Hatching rate (\%) & Survival rate (\%) \\
\hline $\mathrm{T}_{1}$ & $100^{\mathrm{a}}$ & $71.00 \pm 3.06^{\mathrm{ab}}$ & $64.00 \pm 2.08^{\mathrm{ab}}$ & $43.00 \pm 3.79^{\mathrm{ab}}$ \\
$\mathrm{T}_{2}$ & $100^{\mathrm{a}}$ & $84.67 \pm 3.17^{\mathrm{b}}$ & $83.00 \pm 1.53^{\mathrm{b}}$ & $59.33 \pm 2.33^{\mathrm{b}}$ \\
$\mathrm{T}_{3}$ & $66.67 \pm 0.0^{\mathrm{b}}$ & $50.00 \pm 2.89^{\mathrm{a}}$ & $45.00 \pm 0.58^{\mathrm{a}}$ & $32.67 \pm 1.45^{\mathrm{a}}$ \\
\hline \multicolumn{2}{l}{ Values of the parameter in each column with different superscripts $(\mathrm{ab}, \mathrm{a}$, and $\mathrm{b})$ differs significantly $(\mathrm{p}<0.05)}$.
\end{tabular}

\section{Fertilization rate}

Fertilization rates reveal mention worth differences in the effectiveness among the hormones in the 3 different treatments with Ovupin (Table 2). The fertilization rates were recorded as $(71.00 \pm 3.06 \%)$ in $\mathrm{T}_{1}$, while $(84.67 \pm 3.17 \%)$ and $(50.00 \pm 2.89 \%)$ in $\mathrm{T}_{2}$ and $\mathrm{T}_{3}$, respectively (Table 2$)$. ANOVA test results revealed a significant difference among three doses of Ovupin hormone, $\mathrm{T}_{2}$ was significantly $(\mathrm{p}<0.05)$ higher than $\mathrm{T}_{3}$ and $\mathrm{T}_{1}$ (Table 2). Hasan et al. (2021) have observed that fertilization rate was $97 \%$ and $90 \%$ when Hemibagrus menoda was induced by Ovatide hormone at the rate of $5 \& 3 \mathrm{~mL}$ Ovatide $\cdot \mathrm{kg}^{-1}$ body weight for female and $2.5 \& 1.5 \mathrm{~mL}$ Ovatide $\cdot \mathrm{kg}^{-1}$ body weight for male which is higher than the present findings. Mollah et al. (2008) reported that for riverine catfish (Rita rita), fertilization rate was $71.66 \pm 7.64 \%$ when female treated with $100 \mathrm{mg} \mathrm{PG} \cdot \mathrm{kg}^{-1}$ body weight while those treated with $120 \mathrm{mg}$ $\mathrm{PG} \cdot \mathrm{kg}^{-1}$ body weight fish showed $12.50 \pm 2.50 \%$ fertilization. The fertilization rate is lower than the $98 \%$ fertilization rate found in Heteropneustes fossilis injected with Pituitary Gland (PG) extract at $75 \mathrm{mg} / \mathrm{kg}$ 
body weight (Ali et al., 2014). Lower fertilization rate (75\%) was recorded for Cirrhina reba (Verghese 1969). The present findings agree with Haniffa and Sridhar (2002) who observed that irrespective of hormones and fish species, fertilization in Channa punctatus was $70 \%$ and above.

\section{Hatching rate}

The hatching rate was observed $(64.00 \pm 2.08 \%),(83.00 \pm 1.53 \%)$ and $(45.00 \pm 0.58 \%)$ in three treatments $T_{1}, T_{2}$ and $T_{3}$, respectively (Table 2). In $T_{2}$, the highest hatching rate was reported, while $T_{3}$ recorded the lowest hatching rate. Further, hatching rate in $\mathrm{T}_{2}$ was found significantly $(\mathrm{p}<0.05)$ higher than that of $\mathrm{T}_{3}$ and $\mathrm{T}_{1}$ (Table 2). Islam (2002) have observed that hatching rate of (76.21\%) for Ompok pabda in a PG dose of $18 \mathrm{mg} / \mathrm{kg}$ and lowest (36.59\%) at a dose of $20 \mathrm{mg}$ PG/kg body weight of fish. Begum et al. (2001) reported that hatching rate was $38 \%$ as the highest for Shing, Heteropneustes fossilis injected with PG dose of $75 \mathrm{mg} / \mathrm{kg}$ body weight. Akhteruzzaman et al. (1992) and Kohinoor et al. (1990) also observed the same variation during their induced breeding trials. Marimuthu and Haniffa (2010) have observed that induced breeding experiments among three doses of ovaprim showed the best result in the form of hatching rate $(96.3 \%)$.

\section{Survival rate}

The survival rate was observed $(43.00 \pm 3.79 \%),(59.33 \pm 2.33 \%)$ and $(32.67 \pm 1.45 \%)$ in three treatments $T_{1}, T_{2}$ and $T_{3}$, respectively (Table 2). Among the three treatments with Ovupin, the highest survival rate was recorded in $\mathrm{T}_{2}$ while the lowest survival rate was in $\mathrm{T}_{3}$. A significantly $(\mathrm{p}<0.05)$ higher survival rate was found in treatment $\mathrm{T}_{2}$ in comparison with $\mathrm{T}_{3}$ and $\mathrm{T}_{1}$ (Table 2). Hasan et al. (2021) have observed that survival rate was $85 \%$ and $80 \%$ when Hemibagrus menoda was injected with Ovatide hormone at the rate of $5 \& 3 \mathrm{~mL}$ Ovatide $\cdot \mathrm{kg}-1$ body weight for female and $2.5 \& 1.5 \mathrm{~mL}$ Ovatide $\cdot \mathrm{kg}-1$ body weight for male which is higher than the present findings. The survival rate of 5-day old hatchling of Mystus vittatus varied from 55.5-68\% (Sarker et al. 2002, Alam et al. 2006, Islam et al. 2011), which is lower than the present findings. Survival rate noted in this study is remarkably higher than that obtained by Haniffa and Sridhar (2002) who reported that survival rate of $55 \%$ in Channa punctatus injected $3000 \mathrm{IU} \mathrm{HCG} / \mathrm{kg}$ body weight.

The time interval between the first hormonal injection of Ovupin and ovulation (latency period) varied between 24 and $25 \mathrm{~h}$ and occurred within a temperature range of $26-29^{\circ} \mathrm{C}$. Tan-Fermin and Emata (1993) reported that latency period of 12-16 hrs when PG and ovaprim were used for induced breeding of Clarias gariepinus and Clarias macrocephalus which is extremely lower than the present findings. Mollah and Tan (1982) reported that when the temperature was high, the incubation period was short and consequently affects the hatching and survival rate of the eggs of Clarias macrocephalus. Okere et al. (2015) stated that the reproductive output was better when the latency period was short. Pillay (1996) mentioned that for successful induced breeding, the application of the appropriate dose of hormone is the key factor.

Hemibagrus menoda is one of the most valuable catfish in our country which has high demand to the consumers but its biodiversity is undergoing fast declining day by day. Developed protocol of breeding will help the hatchery managers to protect this nearly threatened species from the risks of extinction. On the basis of the highest percentage of ovulation, fertilization, hatching and survival rate, single dose of $6 \mathrm{~mL}$ Ovupin $\cdot \mathrm{kg}^{-1}$ body weight for female and $2 \mathrm{~mL}$ Ovupin $\cdot \mathrm{kg}^{-1}$ body weight for male could be considered as the effective dose for the induced breeding of $H$. menoda in a $2 \delta^{\lambda}: 1 q$ ratio. The findings of the study will be helpful in the commercial hatcheries as it is cost savings. It enables to produce the high-quality seeds by dint of proper application of Ovupin hormone dosages in menoda cat fish. 


\section{ACKNOWLEDGMENTS}

Authors are thankful to the Field Laboratory Complex of Fisheries Faculty, Bangladesh Agricultural University, Mymensingh, Bangladesh for assistance in conducting the research successfully. The authors gratefully acknowledge the financial assistance of the Ministry of Science and Technology, Bangladesh for funding under National Agricultural Technology Transfer Programme-Phase II Project (NATP-2).

\section{REFERENCES}

Achionye-Nzeh, C. G. and I. Obaroh. 2012. Ovaprim doses effects on eggs of African Mudfish Clarias gariepinus. Int. J. Life Sci. Pharma. Res. 2(2): 6-9.

Adebayo, O. T. and O. M. Popoola. 2008. Comparative evaluation of efficacy and cost of synthetic and nonsynthetic hormones for artificial breeding of African catfish (Clarias gariepinus, Burchell 1822). $J$. Fish. Aquat. Sci. 3(1): 66-71.

Akhteruzzaman, M., A. H. M. Kohinoor and M. S. Shah. 1992. Observations on the induced breeding of Puntius sarana (Hamilton). Bangladesh J. Zool. 20(2): 291-295.

Alam, M. J., M. Begum, M. A. Islam and H. K. Pal. 2006. Spawning behavior and induced breeding of an estuarine catfish, Mystus gulio (Ham.). Bangladesh J. Fish. Res.10(2): 101-109.

Ali, M. F., M. Rahman, M. K. Bashar, R. Rahmatullah, M. Hadiuzzama and M. R. Amin. 2014. Comparative study on induced breeding of shing, Heteropneustes fossilis (Bloch) between HCG and PG with different combination. Int. J. Fish. Aquat. Stud. 2(2): 104-108.

Ayinla, O. A. and G. R. Akande. 1988. Growth response of Clarias gariepinus (Burchell, 1822) on silagebased diets. Nigeria Institute for Oceanography and Marine Research (NIOMR), Lagos, Nigeria. 19pp.

Begum, N., M. A. Rahamn, M. G. Hussain and M. A. Mazid. 2001. Effect of carp PG doses on induced breeding of Shing, Heteropneustes fossilis (Bloch). Bangladesh J. Fish. Res. 5(2): 145-148.

Brzuska, E. and J. Adamek. 1999. Artificial spawning of European cattish (Silurus glanis L.); stimulation of ovulation using LHRH-a, Ovaprim and carp pituitary extract. Aquac. Res. 30: 59-64.

Cheah, M. S. and C. L. Lee. 1980. Induced ovulation of the Australian eel-tailed catfish Neosilurus ater (Perugia) with ovaprim. Asian Fish. Sci. 13: 87-96.

Haniffa, M. A. and S. Sridhar. 2002. Induced spawning of spotted murrel (Channa punctatus) and catfish (Heteropneustes fossilis) using human chorionic gonadotropin and synthetic hormone (ovaprim). Veterinarski Arhiv. 72(1): 51-56.

Hasan, M. Z., M. F. Islam, S. A. Haque, M. S. Islam, M. M. Rahman and M. I. Miah. 2021. Dose Optimization of Ovatide Hormone for Induced Breeding of Freshwater Gang Magur, Hemibagrus menoda (Hamilton, 1822). Res. Agric. Livest. Fish. 8(1): 171-179.

Hoque, M. T., F. M. Yusoff, A. T. Law and M. A. Syed. 1998. Effect of hydrogen sulphide on liver somatic index and Fulton's condition factor in Mystus nemurus. J. Fish Biol. 52: 23-30.

Islam, M. M. 2002. Dose optimization for induced breeding of Ompok pabda (Hamilton, 1822) and their larvae and fry rearing. Master's Thesis. Department of Fisheries Management, Bangladesh Agricultural University, Mymensingh, Bangladesh. 123pp.

Islam, M. F., M. I. Miah, M. J. Uddin, K. R. Hasan and K. Bithy. 2011. Effect of Pituitary Gland (PG) Doses on Induced Breeding of Jat Puti, Puntius sophore (Hamilton). Bangladesh J. Seed Sci. Tech. 15(1\&2): 211-216.

Islam, S. S., M. S. Shah and M. L. Rahi. 2011. Study of fecundity and induced breeding of Mystus vittatus. Bangladesh J. Zool. 39(2): 205-212. 
IUCN, Bangladesh. 2015. Red List of Bangladesh: A Brief on Assessment Result 2015. IUCN International Union for Conservation of Nature. Bangladesh Country office, Dhaka, Bangladesh. 24 pp.

Kohinoor, A. H. M., M. Akhteruzzaman, M. G. Hussain and M. S. Shah. 1990. Observation on the breeding of 'Koi' fish, Anabas testudineus (Bloch) in Bangladesh. Bangladesh J. Fish. Res. 14(1-2): 73-74.

Marimuthu, K. and M. A. Haniffa. 2010. Induced Spawning of Native Threatened Spotted Snakehead Fish Channa punctatus with Ovaprim. Asian Fish. Sci. 23: 60-70.

Marimuthu, K., N. Satthiyasilan, M. A. Rahman, A. Arshad, M. G. Raj and J. Arockiaraj. 2015. Induced ovulation and spawning of African catfish Clarias gariepinus using ovaprim. J. Environ. Biotech. Res. 1(1): 2-9.

Mollah, M. F. A., M. R. Amin, M. N. Sarowar and Muhammadullah. 2008. Induced breeding of the riverine catfish Rita rita. J. Bangladesh Agril. Univ. 6(2): 361-366.

Mollah, M. F. A. and E. S. P. Tan. 1982. Effects of incubation temperature on the hatching of catfish (Clarias macrocephalus Gunther) eggs with an illustration on the larval stages. Malay. Nat. J. 36: 123131.

$\mathrm{Ng}, \mathrm{H}$. H. and C. J. Ferraris. 2000. A review of the genus Hemibagrus in Southern Asia with descriptions of two new species. Proceedings of California Academic Science. 52(11): 125-142.

Okere, B., F. Alviano, R. Costa, D. Quaglino, F. Ricci, M. Dominici and L. Iughetti. 2015. In vitro differentiation of human amniotic epithelial cells into insulin-producing 3D spheroids. Int. J. Immunopath. Ph. 28(3): 390-402.

Olubiyi, O. A., O. A. Ayinla and A. A. Adeyemo. 2005. The effects of various doses of ovaprim on reproductive performance of the African catfish Clarias gariepinus (Burchell) and Heterobranchus longifilis (Valaenciennes). Afr. J. Applied Zool. Environ. Biol. 7: 101-105.

Pillay, T. V. R. 1996. Aquaculture: Principles and Practices. Fishing News Books Ltd., London, UK. 175pp.

Rahdari, A., A. Gharaei and M. Ghaffri. 2014. Spawning latency in hormonal induced reproduction of Snow trout (Schizothorax zarudnyi Nikoiskii, 1897). Iranian J. Biotech. 12(1): 61-65.

Rahman, A. K. A. 2005. Freshwater Fishes of Bangladesh. 2nd ed. The Zoological Society of Bangladesh, Department of Zoology, University of Dhaka, Dhaka. 394pp.

Sahoo, S. K., S. S. Giri and A. K. Sahu. 2005. Effect on breeding performance and egg quality of Clarias batrachus (Linn.) at various doses of ovatide during spawning induction. Asian Fish. Sci. 18: 77-83.

Sarker, P. K., H. K. Pal, M. M. Rahman and M. M. Rahman. 2002. Observation on the fecundity and gonadosomatic index of Mystus gulio in brackish waters of Bangladesh. India. J. Biol. Sci. 2: 235-237.

Shinkafi, B. A. and B. D. Ilesanmi. 2014. Effect of varying doses of ovatide on the breeding performance of African catfish (Clarias gariepinus Burchell, 1822) in Sokoto, Northwestern Nigeria. Asian J. Animal Sci. 8(2): 56-64.

Tan-Fermin and J. D. Emata. 1993. Induced spawning by LHRH-a and pimozide in the catfish Clarias macrocephalus (Gunther). J. Applied Ichthyol. 9: 86-96.

Verghese, P. U. 1969. Effect of pituitary hormone injection on the carp, Cirrhina reba (Ham.) in relation to day-length and temperature. Indian J. Zool. 10: 155-160.

Zohar, Y. and C. C. Mylonas. 2001. Endocrine manipulation of spawning induction in cultured fish from hormone to gene. Aquaculture. 197: 99-139. 